\title{
Article
}

\section{Jacob Gordin: The Religious Crisis in Jewish Thought}

\author{
Ori Werdiger
}

check for

updates

Citation: Werdiger, Ori. 2022. Jacob Gordin: The Religious Crisis in Jewish Thought. Religions 13: 44. https://doi.org/10.3390/rel13010044

Academic Editors: Elias Sacks and Andrea Dara Cooper

Received: 3 October 2021 Accepted: 28 December 2021 Published: 1 January 2022

Publisher's Note: MDPI stays neutral with regard to jurisdictional claims in published maps and institutional affiliations.

Copyright: (C) 2022 by the author. Licensee MDPI, Basel, Switzerland. This article is an open access article distributed under the terms and conditions of the Creative Commons Attribution (CC BY) license (https:// creativecommons.org/licenses/by/ $4.0 /)$.
Anne Tanenbaum Centre for Jewish Studies and the Department of Philosophy, The University of Toronto, Toronto, ON M5R2M8, Canada; o.werdiger@utoronto.ca

\begin{abstract}
This article offers an English translation of an essay published in 1946 by Jacob Gordin (1896-1947), a Russian-Jewish philosopher of religion, who is considered the founding figure of the postwar Paris School of Jewish Thought (École de pensée juive de Paris). In "The Religious Crisis in Jewish Thought", Gordin presented a sweeping meta-narrative of the history of Jewish thought, formulated as a history of repeated "religious crises", both existential and intellectual. In Gordin's condensed narrative, these crises could be detected in the life and philosophy of the most canonical Jewish thinkers inside and outside the tradition: from Abraham the biblical patriarch to Hermann Cohen, through a diverse list including the rabbinical sage Elisha Ben-Abuyah, Philo, Halevi, Maimonides, and Spinoza. In an introduction to Gordin's text, I provide a brief biography, locate Gordin in existentialist discourse of the early postwar years, and discuss the affinities between Gordin's “The Religious Crisis” and Levinas's and Sartre's early reflections on the Jewish question.
\end{abstract}

Keywords: Jewish Thought; École de pensée juive de Paris; postwar France; Existentialism; Jacob Gordin; Emmanuel Levinas; Maimonides; Hermann Cohen; Jean-Paul Sartre; Kierkegaard

\section{Introduction}

For Jewish thought in France, the years immediately following the Second World War presented, arguably in the most acute sense, the question of the meaning of Judaism. After the horrors of two global wars, and the Shoah (Holocaust) in particular, questions regarding individual Jewish identity and collective Jewish history were especially pressing. Indeed, from the perspective of many Jewish youth in France, and in postwar Europe more generally, Judaism often meant, in the negative, a guarantee for persecution, if not also probable death. The following text, the title of which, rendered from the original French, is "The Religious Crisis in Jewish Thought" (Gordin 1946), offers some positive answers to the questions of the meaning of Judaism and of being a Jew in a postwar world.

The composer of this essay, Jacob Gordin (1896-1947), was a Russian-Jewish philosopher of religion, an expert on the leader of Marburg neo-Kantianism, Hermann Cohen, as well as a scholar of medieval Jewish philosophy and student of kabbalah (Bernheim and Poliakov 1982; Dmitrieva 2015; Gordin 1995; Friedlander 1990; Levinas 1990; TrautmannWaller 2013). Born in the Lithuanian town of Dunaburg (Yiddish: Dvinsk; today: Daugavpils, Latvia), Gordin's childhood and early adult years were spent in St. Petersburg. After active involvement in the political and intellectual ferment of the early years of the Russian revolution, Gordin immigrated to Berlin in 1923. During a most productive decade, Gordin became an affiliated researcher at the Akademie für die Wissenschaft des Judentums, alongside figures such as Gershom Scholem and Leo Strauss. Under the auspices of this central institution of Jewish studies (Myers 1992), Gordin published a doctoral thesis on the theory of infinite judgement, which involved an extended discussion of Hermann Cohen's logic and its comparison with those of Maimon and Hegel (Gordin 1929). Following the Nazi rise to power in 1933, Gordin and his family moved to Paris, where, failing to secure an academic position, he found a job as librarian for the Alliance Israélite Universelle. During that time, Gordin made the acquaintance of Emmanuel Levinas, became involved in various intellectual circles, and lectured and published on Jewish medieval philosophy. In the early 
years of the Second World War, Gordin and his wife worked at a house for Jewish children organized by the French-Jewish Scouts (Eclaireurs Israélites de France, EIF) (Michel 2003). There, the previously anonymous Gordin began to give lectures in Jewish philosophy and kabbalah to young Jewish members of the Resistance. He was soon adopted by the EIF as one of its intellectual and spiritual guides, and taught in a "school for prophets" (École des prophètes) clandestinely run by the movement until the end of the war (Gordin 1995, pp. 313-14). After the liberation and until his death in 1947, Gordin continued to teach for the EIF and in various forums in Paris (Aslanoff 2005; Lehr 2013).

While Gordin of the interwar years was closer to the scientific ethos of the Wissenschaft des Judentums movement, in the postwar years, he seems to have internalized the kabbalistic ideas which he had begun studying earlier in the 1920s. Gordin's postwar lectures, as described by Levinas, drew on "the riches of the Midrash and Jewish mysticism" yet were "sustained by a remarkable philosophical culture" (Levinas 1990, p. 169). Deeply concerned with questions of individual existence and the philosophy of history, Gordin viewed the Jewish people as a spiritual center of universal human history. The chief Jewish task, for Gordin, was to lead the global metaphysical struggle against evil and suffering, until the messianic age of redemption. This task demands of Judaism to preserve its confessional and markedly a-political identity while carrying on a diasporic collective existence (Gordin 1950). Despite his premature death in 1947, due to his personality, erudition, and influence, Gordin is considered the founder of the Paris School of Jewish Thought (École de pensée juive de Paris). This school included central thinkers of French-Jewry in the postwar years, such as Léon Askenazi, Eliane Amado Lévy-Valensi, André Neher, Renée Neher-Bernheim, and Levinas (Banon 2017; Nordmann 2019).

"The Religious Crisis in Jewish Thought" is not an academic article. Its style is apodictic rather than argumentative, and it should be read as a popular and pedagogical essay, aimed at Gordin's specific audience, that is, young French-Jewish members of the EIF. Relatedly, the essay was composed at a time when Gordin was not in good health, and, as can be noted, it does not seem to have undergone an editing process. ${ }^{1}$ This essay may be described as an existentialist retelling of the history of Jewish thought from the Bible and up to Gordin's days. For Gordin, this is a history of a double-layered perpetual crisis, that demands of each Jewish individual to make two respective choices. On its initial level, for Gordin, this crisis occurs through the daily Amidah prayer, that faces the Jew with the "problem of God". This encounter with God, that is mediated, according to Gordin, by the Bible "which is the divine word itself", constitutes the Jewish self [moi] as absolutely free and thereby under responsibility to make the primary choice: whether to answer the divine call and "enter into the mysterious paradise of the tradition" or refuse it. The secondary choice, that for Gordin is also dependent upon the first, is between two competing cultural options: one is that of Jewish tradition, which for Gordin is attentive to the concrete individual, their freedom, and their collective and personal history, all of which are corroborated with the Jewish insistence on a personal God; the second option, described by Gordin often as "non-revealed", is that of Western culture. For Gordin, Western philosophy is deeply influenced by the pagan concepts of "Greek wisdom", those which, Gordin insists, promote a fatalistic worldview wherein the individual is lacking agency and their life is determined by impersonal and immutable laws of nature.

While this daily existential crisis occurs, in theory, for each Jew, in Gordin's essay, the protagonists who express the "religious crisis" most strongly are central figures in the history of Jewish thought. Gordin opens the essay with Abraham the biblical patriarch, whose chief achievement is not, as Kierkegaard suggested in an earlier and influential narrative of religious crisis, in keeping his faith in the face of the absurd (Kierkegaard et al. 2006). Rather, in Gordin's depiction, drawing on rabbinic sources, Abraham's achievement lay in his intellectual break with commonly held beliefs in astral determination of human fate. This act, in turn, allowed Abraham to then hear the divine call, and actualize his cognitive move by physically leaving his homeland and thus inaugurating a future oriented world history. After Abraham, the people coming out of Egypt repeated, for Gordin, a 
similar act of cognitive and physical breaking with natural determination, this time on a collective rather than individual scale. More than biblical history, however, Gordin is interested in Jewish history after the encounter with "the Greek and Roman civilizations of antiquity". It is primarily into this encounter, characterized as a crisis of struggle against "Greek wisdom", that Gordin brings the most canonical figures in the history of Jewish thought. Among them, it is Judah Halevi who Gordin sees as the most successful in withstanding the Greek philosophical challenge, while Maimonides, discussed most extensively by Gordin, is shown as one who won the battle but lost the war. Moving to the early modern era, Gordin discusses Spinoza together with an earlier Crypto-Jewish thinker, Uriel da Costa, who was also excommunicated by the Jewish community. ${ }^{2}$ Gordin detects the Jewish crisis in da Costa's tragic life, which for Gordin is a manifestation of the incompatibility between the Jewish principle of the immortality of the soul "the cornerstone of our faith", and the "intellectual demands of the renaissance". ${ }^{3}$ Unlike the sympathetic treatment of da Costa, Spinoza is treated by Gordin with a mix of respect (for his intellectual talent) and abhorrence (for his arguably anti-Jewish attitudes). Spinoza's ideas, described as a destructive insertion of Greek wisdom into modern Jewish thought, are claimed by Gordin to be continuously "gnawing" at the Jewish heart. The last figure discussed in the essay, Hermann Cohen, is for Gordin a tragic hero, representing the most recent failed attempt to synthesize the Biblical heritage with modern Western philosophy. ${ }^{4}$

Despite the non-academic style of "The Religious Crisis in Jewish Thought", many of the claims introduced in this essay were previously developed and argued by Gordin elsewhere in a more rigorous and scholarly form. This is particularly the case in Gordin's treatments of Maimonides (for example Gordin 1934), Spinoza (Gordin 1935a), and Cohen (Gordin 1935b). Yet the most productive context within which this essay should be located, I suggest, is in relation to two important philosophical meditations on the "Jewish question" that appeared in France one year after the publication of Gordin's piece. The first is Jean-Paul Sartre's Réflexions sur la question juive (Sartre 1947). This work, more a phenomenological exploration of anti-Semitism than of Judaism, suggested, to many of its Jewish and non-Jewish readers, that Jewish identity is passively constructed by the attitude of the non-Jewish majority. For Sartre in Réflexions, while there is no political solution to the Jewish question, there might be an ethical and existential one. A Jew is always free to choose whether to accept to the full the status determined by society, and lead an "authentic," in Sartre's understanding, Jewish life (an act Sartre seemed to have endorsed), or to try to avoid and run away from their (Jewish) reality. The second article, itself a response to Sartre, is Levinas's "Être juif" (Being Jewish) (Levinas 1947, 2007). In this short piece, Levinas reconceived of Judaism ontologically, as a fact that precedes any sociality and towards which anti-Semitism is a primitive reaction to unexplained mysterious experience. Against Sartre, as well as Heidegger, Levinas rejected a concept of freedom that is independent of the past, and found it, instead, in an absolute Jewish passivity built on a sense of being created and elected by a volitional God:

To do the will of God is in this sense the condition of facticity. The fact is possible only if, beyond its power to chose itself ... it has been chosen, that is, elected. The past that creation and election introduce into the economy of being ... communicates to the present the gravity of a fact, the weight of an existence... Jewish existence is thus the fulfillment of the human condition as fact, personhood and freedom. And its entire originality consists in breaking with a world that is without origin and simply present. It is situated from the very start in a dimension that Sartre cannot apprehend. It is not situated for theological reasons, but for reasons of experience. Its theology explicates its facticity. (Levinas 2007, pp. 209-10)

In "Being Jewish", Levinas intervenes in a Heideggerian informed existentialist discourse in postwar France. Unlike Levinas, Gordin's discussion of Judaism and crisis participates in the neo-Hegelian and early existentialist discourse of the interwar era, possibly with 
Barthian crisis theology in mind. ${ }^{5}$ Still, without what may be read as Levinas's particular sensitivity, or apologetic constraints vis à vis Sartre and Heidegger, "The Religious Crisis in Jewish Thought" offers an existentialist account of Jewish experience that is sometimes closer to Sartre. First, Gordin insists on Jewish freedom as an active and daily exercise, that is not subordinated to a commanding divine will. Moreover, while Levinas seeks to restore the past to the present, Gordin, here following Hermann Cohen's philosophy of history (cf. Schwarzschild 1956) emphasizes Judaism as a future oriented religion. Lastly, like other thinkers on the political left and right between the wars, Gordin casts the Jewish crisis as an historical event that demands a clear-cut decision and human resolution (Koselleck 2002). This in contrast to Levinas, who arguably constructs his Jewish being as an alternative to the Heideggerian one, and as such, prior to, and independent of any individual human decision.

And yet, Gordin's "The Religious Crisis in Jewish Thought" and Levinas's "Being Jewish" also share the fundamental argument that the fact of Jewish existence is a positive and independent datum, that does not need antisemitism to construct it. Furthermore, both Gordin and Levinas insist on a concept of freedom that is inherent to Judaism. Finally, in this short piece composed in the brief temporal interlude between the end of the Second World War and the establishment of the State of Israel, Gordin's views on the meaning of Jewish history converge with a central element of Levinas's (postwar) philosophy. For Gordin, the central characteristic of Jewish history is Judaism's staunch and constant challenge to the "pagan" heritage of the West. It is in opposition to this perceived totalitarian, anti-humanist heritage, which Gordin and Levinas detected in different ways in the Western philosophical tradition, that both thinkers invoked the notion of a face. For Levinas, it is the human face, the epiphany of which structures all subsequent ethical relations with the other (Levinas 1969, especially pp. 194-201). And, before Levinas, at the end of his essay authored in 1946, Gordin urged his readers to recall the second commandment uttered during the divine epiphany at Sinai, and resist any ideas or ideologies that obscure the face of God. ${ }^{6}$

\section{Jacob Gordin: The Religious Crisis in Jewish Thought}

As soon as a Jew wishes to become self-aware [of their role], as an individual and as an element of the Jewish People, they are confronted with the problem of God. This is inevitable, since it is from the Bible, which is the Divine Word itself, that the Jewish person draws the primary elements of self-knowledge and of the meaning of the existence of the Jewish people.

The history of the Jewish people began with Abraham, though, at that time, it is only the history of a single family. Abraham heard divine speech, a divine call, after having passed through what is called today a religious crisis. The midrash recounts how he took account of the insufficiency of pagan divinities, and arrived at the conception of a God that is a supreme ruler of the divinities of different peoples and of the forces of nature. He thereby became capable of hearing divine speech. Having received this call, he was invested with a mission, that necessitated an almost absolute rupture with the past: "Go, leave your country, your people". The midrash adds that, at the same time, Abraham was told: "leave your astrological conceptions"; this means the pagan conceptions, according to which, even today, the universe is dominated by the forces of nature. If the pagans could attain the idea of a supreme God, as was the case of the pagan priest Melchizedek, it would still always be the God of nature.

To cut off the links with the past, to look towards the future, this means to leave the God of nature, to inaugurate what has been called since Abraham's time the true conception of history and of the becoming of man. To the degree that people look behind them (Greco-Roman representations of the Golden Age), they live under the hold of the past, of nature. To have a feeling of history, one must live toward the future. This is the idea that is expressed by the words "leave your astrological conceptions". It was Abraham to whom it was revealed: that man and human history are not ruled by the regular movement 
of astral bodies, but that the will of humans, supported by divine providence, guide human destinies.

Several centuries later, the same experience was reserved for those who went out of Egypt. The exodus out of Egypt was not only a physical liberation but the beginning of a new spiritual era. The biblical text says: "I will judge the Egyptians and their gods". According to the midrash, the supreme God of the Egyptians was linked to the Zodiac sign of Aries (Ammon, the Ram God of Thebes). It was in the time of the reign of the Ram, that is, towards the spring equinox, in the month of Nissan, that the Jewish people were liberated. And the midrash asks how it is possible that this deliverance took place precisely under the sign of the Ram. The answer: God judged the Egyptian divinity and overthrew it. The sacrifice of the paschal lamb symbolizes the Ram deprived of its divine power.

The fall of the god of Egypt is the fall of the astrological system, of the reign of planetary forces. The forces of nature that had been shattered by Abraham as an individual, were [then] definitively shattered by the [Jewish] people in its entirety. This is a repetition and a reinforcement of Abraham's experience.

Biblical speech tells us that, in the same era, God revealed his true name for the first time. And the midrash [asks] why the generation of Egypt were favored to receive the revelation of the divine name, and it provides, among other responses, one that is a little surprising: "This is because they did not take false names when they were in Egypt". No doubt, there is a direct relation between our personal name and the divine name revealed to Moses.

Since that time, the people of Israel behave as a personality that enters into a relationship with the divine person. The tradition describes the encounter between the people and God, at the moment of the exodus out of Egypt, as a time of betrothal (symbolized by the engagement of the Shulamite and the king, in the Song of Songs). A little later, [at] the Sinai revelation, this is the time of marriage, wherein the personality of the people was affirmed further and further. "I will betroth you to me forever" (Hosea 2:21), "For your Creator is your spouse, the Eternal of hosts is his name" (Isaiah 54:5). It is since that era that there simultaneously exist history, and individual man immersed within his history.

Much later, when the people of Israel enter into contact with the great antique civilizations (Greek and Roman), there commences hard and often painful work: of opposing this new culture with the heritage of the tradition, which itself is completely centered on the problem of the individual and freedom. [With] each generation, the heritage of the tradition is created anew through the trial of a religious crisis, which thereby becomes one of the constitutive elements of a truly Jewish religious life.

It is not by chance that prayer is daily and cannot be replaced with one prayer that is valid for the whole week. The problem of the relationship of a Jew with their Creator is posed in a dramatic way and it must be resolved, each morning and each evening. There are however periods of calmness for individuals as well as for generations. Yet it is sometimes enough even for an incident of quotidian life to pose this problem anew.

If this latent crisis becomes more acute, so that it is revealed under another aspect, the relationship between the tradition, Jewish faith, and the individual becomes painful; emerging out of the abstract plane, it becomes a conflict between the conception of the God of history, the God of the individual, on the one hand, and the God of nature on the other hand. This opposition almost corresponds to the opposition between the sacred and the profane: what occurs in ourselves, in our individuality, this would be the sacred; the rest, that is to say the natural evolution of humanity, this would be the plane of the profane.

This is an enduring crisis, but sometimes it happens that it is exteriorized and takes the form of the antagonism between the biblical conception of the " $\mathrm{I}$ " [moi] and of man, and the philosophical ideas of non-revealed wisdom.

It is impossible to trace, in such a short article, all the divergences between biblical wisdom and the non-revealed wisdom of Greek philosophy. We will set aside the problem of the religious crisis as it is presented in the Bible itself (Job, Ecclesiastes, and Proverbs). We will only indicate that, in antiquity, the tradition was aware of a real danger, menacing 
to Jewish spirituality: "Above all do not succumb to Greek wisdom", such is one of the warnings one continually encounters in the Gemara [Talmud], the midrashim, etc. In many cases, this saying receives an accent of hostility towards all that is located outside the enclosure of the Torah, it becomes an interdiction to study profane, Greco-Roman sciences. This interdiction, however, was never total. [There are] those of whom one could be sure [, who] could study Greek wisdom and draw from it profane utility, which even strengthened them in their struggle.

It is told for example that Rabbi Samuel of Nehardeah, who raised the standard of the struggle against the Greeks, was at the same time well versed in the profane astronomical and astrological sciences of the era. He was pressed to admit that his anti-Greek struggle contradicted his scientific preoccupations; he offered a humoristic response, that shows the paradoxical character of the situation: "Yes, I read their astronomical writings, but only in moments that could not be utilized for the study of the Torah, when I go to private places [the bathroom] ..."

Yet it happened that, at the very same time, the best did succumb: and hence, Rabbi Elisha ben Abuyah, nicknamed "Acher", "the Other": he wrestled all his life with the opposition between the Torah and Greek philosophy. But it should be recognized that a man like Acher, despite his personal incertitude, remained within the community, and a sage with the authority of Rabbi Meir always held him in esteem and maintained a personal friendship with him. In contrast, a philosopher such as Philo of Alexandria, a representative figure of Hellenistic thought, did not leave a single trace in the Jewish tradition. He wanted to find a synthesis between the God of the Bible and the God of Plato and Aristotle. However, as far as we know (leaving aside the actions of his diplomatic voyages to Rome) one does not find a trace of his influence in the Jewish tradition.

If there did all the same remain some traces of his teaching, there are only philosophical terms; his [philosophical] conception itself did not have a direct influence. However, he indirectly influenced Judah Halevi, who, in his Kuzari, appealed to the "Davar Elohim" which was almost close to Philo's Logos. Nevertheless, it was he [Halevi] who proclaimed the antithesis between the God of the philosophers and the God of Israel: "The God to whom each person can speak". We find much later [again], in Pascal, this opposition between the God of Abraham, Isaac, and Jacob, and the God of the philosophers. The reason for this opposition is the same as that which emerges from the biblical tradition: The Jewish God is a God of the individual man, a personal God; the pagan God is a God of the species-man, of the entity: man.

In this moment, it looks like the relationship between the biblical conception and the non-revealed conception were finally severed. [Yet] a century passes and we find ourselves returning to the same problem with Maimonides.

Maimonides, while fascinated by the splendor of Greek thought, of the thought of Aristotle, felt the profundity of the biblical voice. He did not transgress it. He opposed Aristotle; he refused the Greek ideas about the origin of the world. [This is] since Aristotle and non-biblical mentality, in a general way, do not recognize the existence of the individual, of the person. The philosopher only treats the idea of God, the idea of man in general, like the idea of the animal, of the plant, etc. All these ideas, for the philosopher are on the same plane; they do not see the superiority of man before God, in relation to other species; they fail to recognize the scientific character of human existence.

"If a great wind blows, which strips the leaves from a tree, makes the wall of a house fall, and, on the sea, drowns a ship with its voyagers, there does not exist, for Aristotle, any difference between the fall of the leaves, of the wall, and the wreck of the righteous who might be found on the ship". "For Aristotle, there is no difference between the death of an ant crushed by a stone, and that of a man buried, during prayer, inside a house that collapses on him" (Guide for the Perplexed III, 17).

Aristotle speaks of man in general. In contrast, Maimonides puts man as such at the center, in his personal individuality. We find ourselves here in the presence of two theses: the Greek thesis of the eternity of the world, which stifles the individual, and the biblical 
thesis of the created world, of individuality, which grants to individuals all of their value. Maimonides is thereby found to be in the lineage of Judah Halevi: "God speaks separately with each person". And so, everything seems to be in order: revealed thought delineates the limits of reason which would like to be self-sufficient. However, the empire of Greek thought (which will become free thought) is very strong: a thinker such as Maimonides, despite everything, does not feel himself standing on stable ground.

Since its appearance, the Guide for the Perplexed has been attacked as a dangerous work, expressive of ideas which "belong to the spirit of the adversary". Some contemporaries made the play of words: "The Guide for the Perplexed perplexes its readers". The following centuries were able to affirm that the Great Eagle of the Synagogue succumbed to the Greek peril. It is a fact that the highest religious authority in Maimonides's time, Samuel Ben Eli of Bagdad, the "Prince of Exile" on whom ultimately depended the ordination of rabbis, rector of the Talmudic academy, condemned Maimonides's system for a single reason: despite all his affirmations, Maimonides could not grant the fundamental principle of Judaism, the resurrection of the dead.

We are in the presence of a truly dramatic dialogue: Maimonides swears on multiple occasions that he believes in the resurrection of the dead: in his commentary on the Mishna, where he placed it in his thirteen articles of faith, he insisted on the belief in the resurrection as an absolute dogma of the Jewish confession.

Samuel Ben Eli did not believe him. In a moment of desperation, Maimonides wrote to one of his intimates, a student, Joseph Ben Akhini: "You know well that I have always taught the belief in the resurrection of the dead, cursed is the one who says the contrary ... " No one believed him, neither his contemporaries, nor those who, many centuries later, ponder over his writings. He was therefore obliged to prop up his affirmations: this is what he says, more or less, near the end of Yad Hazaka: "In the time of the Messiah, death will be defeated; all will be resurrected, but only for a limited time, and then they will succumb to death again". An unheard-of paradox: This is at least the true confession of the impossibility of escaping from the century's grasp: one is resurrected to die anew.

For one who searches for their path, a few drops of Greek poison are enough to destabilize their faith and throw them, torn, into the abyss of a religious crisis.

The same problem will be posed again several centuries later, in the era when appeared the vainglorious thought of Spinoza. Independently of the intrinsic philosophical value of the Ethics, undoubtedly the work of Spinoza in which is revealed to us the true kitchen where Spinoza's theorems of the Ethics were prepared, is the Theologico-Political Treatise, which represents one of the most violent attacks, not only on biblical conceptions, but on the spiritual activity of the Jewish people in general. This has to do with some personal difficulties of Spinoza, who was caught in an inextricable web of spiritual and even financial submission to those who represented the anti-Jewish spirit of that era, the milieu of Quakers and the Socinian Mennonites of Holland. However, it is not this sad aspect of the treason committed by Spinoza that interests us here. To understand the new spiritual situation, which was the expression of the religious crisis of that time, it is better to study one of Spinoza's true predecessors, Uriel d'Acosta.

This person, with a Marrano milieu as origin, was a doctor in Catholic theology from the University of Salamanca, who was also a characteristic figure of the religious orders until adulthood. Then he became Jewish again: other than his Jewish blood, it was his spiritual and philosophical preoccupations that led him to Judaism: the question of the immortality of the soul troubled him for philosophical reasons. He did not want to admit to it [immortality of the soul], he who was a precursor of free thought. His Catholic knowledge inspired in him the fallacious idea that the wisdom of Moses was a down to earth, realist wisdom (the Old Testament speaks only of a terrestrial paradise, [while] Christianity opened the gates of heaven). He therefore re-entered the Jewish community, sacrificing his past. And he was deeply surprised to learn that Judaism, towards which he turned, admits of the principle of the immortality of the soul, the cornerstone of our faith and a consequence of the individualization of the human soul; to accept this dogma clashed 
for him with the unyielding forms of Greek and free thought. The end of this tragedy, the suicide of Uriel Acosta, is known. The last words of his testament, written shortly before his suicide were: "In Portugal, among the Christians, I was called Gabriel da Costa, and among the Jews (what demon forced me towards them!) Uriel Acosta.

The point of departure of this crisis is the confrontation between biblical conceptions and the intellectual demands of the renaissance. This desire of Uriel Acosta, and of another contemporary of Spinoza, David de Prado, and above all the near satanic vigor of Spinoza, determined the development of the spiritual difficulties of Jewish thought, all the weight of which we feel today.

Through the unfortunate initiative of Mendelssohn, the father of the spiritual emancipation, Spinoza, with his Marrano heritage, was introduced into the spiritual preoccupations of every Jew who hesitated at the crossroads. It is since that era that, not only the effective attitude of spiritual rebellion, but also the consciousness of the spirit of the West gnaws at the hearts of Jews.

Why did Spinoza play such a sinister role? Because he was a true philosopher, perhaps one of the greatest; because without him, the scope of nineteenth-century European philosophy would have been inconceivable, and because while being of the same spiritual family as Plato and Aristotle, he additionally possessed his Jewish origin, his rabbinical readings, all of which created around his truly non-Jewish mind a false atmosphere of a quasi Judeo-Christian religiosity.

We arrive from there at our period, or at least that of yesterday: One could hardly find a particular case that is more significant than that of Hermann Cohen. This was a man who created a whole library at the beginning of the twentieth century, an illustrious philosopher who drew to the small university of Marburg, where he taught, students from the East and West, from Moscow, Madrid and New York. He erected a synthesis of Judaism and the philosophical and scientific thought of his era; he wanted to reach an overcoming of the religious drama, [this he attempted to do] in his posthumous work: The Religion of Reason, based on Jewish sources (a sort of summa). This man acquainted himself with the Polish Jew, he discovered a new world, and his personal experiences are reflected in his work. And here is an anecdote that is told about him: One day he was giving a lecture in which he spoke with depth and eloquence on the moral value of religious Judaism, on the Biblical God as the sole guarantor of humanity's moral progress, and on peace between humans that will lead to the messianic era of which the prophets spoke. All of this was in good order, all was well distributed, the Bible and Greek philosophy, the Talmud and Kant or Hegel. However, after the magnificent delivery of the conclusion, one of his auditors, a representative of these simple Polish Jews, posed to him an innocent question: "But where is the place of the Creator of the World in your philosophy? Is it the same as the principle guaranteeing the messianic era of which you spoke? And the midrash, the oral and written tradition of the students of Hermann Cohen says that this celebrated author of a whole library did not find any other response but to burst into tears.

Here is the conclusion that we take from this: The religious crisis has always two faces. We experience a crisis as a religious being. The biblical word, which reveals to us that man is a free and individual being, by this very fact demands of us not a blind obedience, but a free decision, a supreme choice in complete liberty: A Jew always has the choice to re-enter the mysterious paradise of the tradition or to refuse it.

To this perennial crisis, the principle of which is renewed and finds its solution in daily prayer, there is added another form of crisis: That of the necessary confrontation between our biblical heritage, continually regained by the preceding choice, and what is called the spirit of the West, or better still, the culture of a non-revealed world.

And here again, a decision must be made, one must pose to one-self the fundamental question: this non-revealed civilization of the West, does it truly contain all the values that are habitually attributed to it, is it truly capable of satisfying all the aspiration of the total human being (body and soul)? 
Are we not obliged to consider this Western culture as another giant with feet of clay? We are not the only ones to pose this question. Without a doubt this debate has been open already for quite some years; there is a worldwide realization of a deep crisis that is shaking all of Western man: it is not only a social crisis but a crisis in all the domains: philosophy, art, morals, value of science, etc.

In truth, for us, all this is not new: We have, from the start, launched a challenge to Greek wisdom, to foreign gods. And to conclude we repeat the second commandment: "You shall not have foreign gods, before my face".

Funding: This research received no external funding.

Institutional Review Board Statement: Not applicable.

Informed Consent Statement: Not applicable.

Acknowledgments: I am grateful to Abraham Igelfeld and Ynon Wygoda for their assistance with the translation, and to the anonymous reviewers and the editors of the special issue for their comments and suggestions.

Conflicts of Interest: The author declares no conflict of interest.

\section{Notes}

1 In the original French version, there were several incorrect references, as well as typographical mistakes. These suggest that Gordin either wrote from memory or, what is also possible, dictated to someone else from memory. In the translation, while I corrected the abovementioned issues, I preferred, when possible, to maintain the original sentence structures as well as the specific terminology used by Gordin. This in order to give the reader a better sense of Gordin's distinct style of expression (see also Aslanoff 2005; Askenazi 1995). With these condsiderations in mind, I also often kept the masculine form, rendering the French "homme" as "man" rather than the more inclusive "human" or "person". Throughout the translated essay, all italicised words are in the original.

2 Like other scholars of his time, Gordin used the then-accepted term, Marranos, to identify Iberian Jews who converted to Christianity in the 14th and 15th centuries, most often by force. However, as scholarship suggests, this term carries a derogatory meaning that associates these converts to Christianity with pigs. In recent decades, scholars as well as many Spanish and Portuguese speaking descendants of these converts use instead the term crypto-Jews (Malkiel 1948; Gitlitz 1996; Hordes 2005).

3 In the essay, Gordin suggests that the notion of the soul's immortality is directly related to Judaism's confirmation of human individuality. As indicated in his more scholarly works, Gordin located his account of individuation in Judaism as another theoretical instantiation of the contrast between the biblical and philosophical God. In addition, Gordin's investment in the notion of individuality may have been inspired by the anarchist thought of Kropotkin, to which Gordin was drawn in his youth (Friedlander 1990). In the immediate postwar context of Gordin's essay, one wonders if the insistence on the immortality of individual souls also served as an implied response to the annihilation of European Jewry during the war. From this perspective, an affirmation of the immortality of souls is a metaphysical affirmation of the survival and continuity of Judaism.

4 This aspect of Gordin's position is closer to that of Franz Rosenzweig in his "Apologetic Thought" (Rosenzweig 2000), on which Gordin explicitly drew in other works (Gordin 1935a). This position is also reminiscent of Leo Strauss's radicalization of Rosenzweig's view regarding the near incommensurability between Judaism and philosophy, as expressed in Strauss's dichotomy between revelation and reason (e.g., Strauss 1952; Batnitzky 2000).

5 It is possible, although not probable, that Gordin did read the early articulation of Sartre's Réflexions, published in Les Temps modernes. Relatedly, it is highly doubtful that Levinas read Gordin's “The Religious Crisis", but he was certainly aware of Gordin's ideas.

6 For a recent treatment of Levinas's notion of the face, see Prepich (2018). I am not suggesting that Gordin's brief appeal to the divine face in 1946 influenced Levinas's complex development and deployment of the secularized notion of the face in the latter's postwar philosophy. Here, I am merely pointing out some similarities between these two thinkers.

\section{References}

Askenazi, Léon. 1995. Jacob Gordin, mon maître 9-17. In Écrits: Le Renouveau de la Penseé Juive en France. Edited by Marcel Goldman. Paris: Albin Michel, pp. 9-17.

Aslanoff, Cyril. 2005. Jacob Gordin en France: Transfert de savoir ou malentendu culturel? Archives Juives 38: 43-55. [CrossRef]

Banon, David. 2017. L'École de Pensée Juive de Paris: Le Judaïsme Revisité sur les Bords de Seine. Strasbourg: Presses universitaires de Strasbourg.

Batnitzky, Leora. 2000. On the Truth of History or the History of Truth: Rethinking Rosenzweig via Strauss. Jewish Studies Quarterly 7: 223-51. 
Bernheim, Renée, and Léon Poliakov. 1982. Gordin, Jacob. In Encyclopaedia Judaica, Events of 1973-1982. Jerusalem: Encyclopaedia Judaica, pp. 268-69.

Dmitrieva, Nina. 2015. Biographical and philosophical landscapes of Jacob Gordin. RGGU Bulletin 148: 125-40.

Friedlander, Judith. 1990. Vilna on the Seine: Jewish Intellectuals in France since 1968. New Haven: Yale University Press.

Gitlitz, David M. 1996. Secrecy and Deceit: The Religion of the Crypto-Jews. Philadelphia: Jewish Publication Society.

Gordin, Jacob. 1929. Untersuchungen zur Theorie des unendlichen Urteils. Berlin: Akademie-Verlag.

Gordin, Jacob. 1934. Actualité de Maïmonide. Cahiers Juifs 10: 6-18.

Gordin, Jacob. 1935a. Benedictus au maledictus (Le cas Spinoza). Cahiers Juifs 14: 104-15.

Gordin, Jacob. 1935b. Maïmonide dans la pensée du XIXe siècle. Cahiers Juifs 16: 124-34.

Gordin, Jacob. 1946. Les crises religieuses dans le pensée juive. Lumière: EIF, Périodique Pour les Chefs 2: 10-18.

Gordin, Jacob. 1995. Écrits: Le Renouveau de la Penseé Juive en France. Edited by Marcel Goldmann. Paris: Albin Michel.

Gordin, Jacob. 1950. La Galouth (D’après Jacob Gordin). In Aspects du Génie d'Israël. Edited by Elian Judas Finbert. Paris: Cahiers Du Sud, pp. 105-25.

Hordes, Stanley M. 2005. To the End of the Earth: A History of the Crypto-Jews of New Mexico. New York: Columbia University Press.

Kierkegaard, Søren, C. Stephen Evans, and Sylvia Walsh. 2006. Fear and Trembling. Cambridge: Cambridge University Press.

Koselleck, Reinhart. 2002. Some questions regarding the conceptual history of "crisis". In The Practice of Conceptual History: Timing History, Spacing Concepts. Stanford: Stanford University Press, pp. 236-47.

Lehr, Johana. 2013. La Thora Dans la Cité: L'émergence d'un Nouveau Judaïsme Religieux après la Seconde Guerre Mondiale. Lormont: Le Bord de l'eau.

Levinas, Emmanuel. 1947. Être juif. Confluences 15-17: 253-64.

Levinas, Emmanuel. 1969. Totality and Infinity: An Essay on Exteriority. Pittsburgh: Duquesne University Press.

Levinas, Emmanuel. 1990. Difficult Freedom: Essays on Judaism. Baltimore: Johns Hopkins University Press.

Levinas, Emmanuel. 2007. Being Jewish. Continental Philosophy Review 40: 205-10. [CrossRef]

Malkiel, Yakov. 1948. Hispano-Arabic Marrano and Its Hispano-Latin Homophone. Journal of the American Oriental Society 68: 175-84. [CrossRef]

Michel, Alain. 2003. Juifs, Français, et Scouts: L'histoire des E.I. de 1923 aux Années 1990. Jérusalem: Editions Elkana.

Myers, David. 1992. The fall and rise of Jewish historicism: The evolution of the Akademie für die Wissenschaft des Judentums (1919-1934). Hebrew Union College Annual 63: 107-44.

Nordmann, Sophie. 2019. Retour à la tradition et ouverture au monde contemporain-L'École de pensée juive de Paris. In La Sécularisation en Question. Religions et Läicités au Prisme des Sciences Sociales. sous la direction de Jean Baubérot, Philippe Portier et Jean-Paul Willaime. Paris: Classiques Garnier, pp. 473-83.

Prepich, Diane. 2018. Levinas and the Face of the Other. In The Oxford Handbook of Levinas. Edited by Michael L. Morgan. New York: Oxford University Press, pp. 243-55.

Rosenzweig, Franz. 2000. Apologetic Thinking. In Philosophical and Theological Writings. Translated and Edited by Paul W. Franks, and Michael L. Morgan. Indianapolis: Hackett, pp. 95-108.

Sartre, Jean-Paul. 1947. Réflexions sur la Question Juive. Paris: P. Morihien.

Schwarzschild, Steven S. 1956. The Democratic Socialism of Hermann Cohen. Hebrew Union College Annual 27: 417-38.

Strauss, Leo. 1952. Persecution and the Art of Writing. Chicago: University of Chicago Press.

Trautmann-Waller, Céline. 2013. Jacob Gordin ou le judaïsme d'un philosophe européen. Saint-Pétersbourg-Berlin-Paris. Archives Juives 46: 30-58. [CrossRef] 